\title{
Intraoperative serum parathyroid hormone level is an indicator of hypocalcaemia in total thyroidectomy patients
}

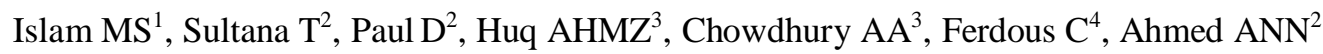 \\ ${ }^{1}$ Department of Surgery, Bangabandhu Sheikh Mujib Medical University (BSMMU), Dhaka, \\ ${ }^{2}$ Department of Clinical Pathology, BSMMU, Dhaka, ${ }^{3}$ Department of Otolaryngology, BSMMU, \\ Dhaka, ${ }^{4}$ Uttara Health Care Center, Bangladesh Institute of Health Science, Dhaka. \\ Email:d.islambulbul@yahoo.com
}

\begin{abstract}
Postoperative hypocalcaemia is the most frequent and common complication after total thyroidectomy. It is necessary to diagnose or to predict hypocalcaemia immediately after total thyroidectomy for minimizing complications. A prospective observational study was carried out in the Department of Clinical Pathology in collaboration with Department of Microbiology \& Immunology, Department of Surgery, Department of Otolaryngology, Bangabandhu Sheikh Mujib Medical University (BSMMU) and Department of Otolaryngology, Dhaka Medical College \& Hospital (DMC\&H), Dhaka, during the period of September 2010 to August 2011 to evaluate intraoperative (20 minutes after total thyroidectomy) parathyroid hormone (PTH) measurement as a predictor of post thyroidectomy hypocalcaemia. Total 65 patients were enrolled in this study those came for total thyroidectomy. Postoperative hypocalcaemia developed in 25 cases. Intraoperative PTH was assessed and significant correlation was found between intraoperative PTH level and development of hypocalcaemia. The sensitivity, specificity, accuracy, positive predictive value, negative predictive value of intraoperative serum PTH for prediction of post total thyroidectomy hypocalcaemia were $84.0 \%, 85.0 \%, 84.6 \%$, $77.8 \%$, and $89.5 \%$ respectively. Because of the high sensitivity, specificity and accuracy of intraoperative serum PTH of this study, the early prediction of hypocalcaemia could be made by single assay of intraoperative serum PTH level at 20 minutes after total thyroidectomy.
\end{abstract}

\section{Introduction}

Total thyroidectomy is generally done for patients with thyroid malignancy, thyrotoxicosis or toxic multinodular goiter and for chronic thyroiditis ${ }^{1}$. Total thyroidectomy is associated with specific complications namely, haemorrhage/haematoma, recurrent laryngeal nerve injury and hypoparathyroidism with subsequent hypocalcaemia ${ }^{3}$.

Post thyroidectomy hypocalcaemia develops as a result of hypoparathyroidism secondary to parathyroid trauma, devascularization or inadvertent removal of parathyroid gland during thyroid surgery ${ }^{4}$. Other postulated explanations include haemodilution, secondary to urinary calcium excretion, calcitonin release and hungry bone syndrome, osteodystrophy and autoimmune fibrosis compromising parathyroid vascularization ${ }^{5}$. Hypocalcaemia is more common in female after total thyroidectomy'.

Patients with acute hypocalcaemia may present with numbness of the distal extremities, carpopedal spasm, laryngospasm, seizure and arrhythmias ${ }^{7}$. To minimize complications and early discharge, we should be able to identify the patients who will be hypocalcaemic ${ }^{\mathbf{8}}$. Postoperative hypocalcaemia may have a delayed onset'. The lowest calcium levels are typically reached at 24 to 48 hours after thyroidectomy. Hypocalcaemia may be present even later on ${ }^{10}$. For that reason, measurement of serum calcium cannot be used as a predictor of hypocalcaemia immediately after thyroid surgery ${ }^{\mathbf{1 1}}$. Because of the short half life of PTH, intraoperative PTH monitoring emerges as an early marker of hypocalcaemia $^{12}$. Postoperative PTH levels less than $15 \mathrm{pg} / \mathrm{ml}$ on the first postoperative day are more sensitive for prediction of hypoparathyroidism $^{\mathbf{1 3}}$. But this assay has been shown to accurately predict hypocalcaemia, following thyroid surgery ${ }^{14}$.

To minimize complications and early discharge, we should be able to identify the patients who will develop hypocalcaemia. The ability of thyroid surgeon to predict which patients are at great risk of developing hypocalcaemia postoperatively could facilitate safe early discharge from hospital with potential cost savings ${ }^{15}$. The efforts of this study 
are to find out the overall incidence of hypocalcaemia, early prediction of hypocalcaemia after total thyroidectomy and to minimize post thyroidectomy complications, which will potentially limit morbidity and early discharge of patients from hospital. The aim of this study is to evaluate intraoperative PTH measurement and to predict post thyroidectomy hypocalcaemia accurately.

\section{Materials and Methods}

This prospective observational study was carried out in the Department of Clinical Pathology in collaboration with Department of Microbiology \& Immunology, Department of Surgery \& Department of Otolaryngology of Bangabandhu Sheikh Mujib Medical University (BSMMU) and Department of Otolaryngology of Dhaka Medical College Hospital, Dhaka, during the period of September 2010 to August 2011. Study protocol was approved by the Ethical Review committee of BSMMU. All patients those came for total thyroidectomy were included in this study irrespective of age and sex. Known patients of hypoparathyroidism and patients of chronic renal failure were excluded from this study. Patients who had serum calcium $<2.0 \mathrm{mmol} / \mathrm{l}$ at 20 minutes, 24 or 72 hours (hypocalcemia) were compared with normocalcemic patients. Normal value of serum calcium lebel was considered ranges from 2.00 to $2.60 \mathrm{mmol} / \mathrm{l}$. The clinical manifestations of hypocalcaemia included numbness of the distal extremities, circumoral paresthesias, carpopedal spasm, confusion, delirium, seizure, laryngospasm, bronchospasm and arrhythmias. The level of intraoperative PTH was determined to predict post operative calcium level. Normal value of PTH lebel was considered ranges from 12 to $145 \mathrm{pg} / \mathrm{ml}$. After taking informed consent, a careful history and the details information were recorded by the investigator in a predesigned questionnaire. With all aseptic precaution $5 \mathrm{ml}$ blood was taken preoperatively for serum PTH \& calcium level measurement. Then intraoperatively $5 \mathrm{ml}$ blood was taken for serum PTH \& calcium level measurement. After 24 hours \& 48 hours of total thyroidectomy, $3 \mathrm{ml}$ blood sample was collected for serum calcium level measurement. Blood samples were stored in refrigerator at $-20^{\circ} \mathrm{C}$ before measurement of serum PTH. Serum PTH was measured in batches. Serum PTH was measured using chemiluminescent assay by Immulite 2000 $\mathrm{XPi}$ in the Department of Microbiology \& Immunology, BSMMU. Serum calcium was measured by semi automated analyzer (3000 Evolution) in the Department of Clinical Pathology, BSMMU. The validity of intraoperative PTH in prediction of hypocalcaemia after total thyroidectomy was identified by calculating sensitivity, specificity, accuracy, positive predictive value and negative predictive values. Statistical analyses of the results were obtained by paired $\&$ unpaired Student t-test, Pearson's correlation test, Validity test using window based computer software devised with Statistical Packages for Social Sciences (SPSS-15).

\section{Results}

In this study, 65 patients were included. The mean $( \pm$ SD) age of the patients was $39.15 \pm 13.18$ years with age range from 15 to 75 years. Males were $22.5 \%$ and females were $77.5 \%$. The incidence of hypocalcaemia was $38.5 \%$ in the study patients. Post operative hypocalcaemia developed in 25 cases. Among them 15 hypocalcaemia were developed intraoperatively, 7 were developed after 24 hours and 3 were developed after 48 hours of total thyroidectomy. Only 3 patients out 25 hypocalcaemic patients developed symptoms of hypocalcaemia.

The mean $( \pm \mathrm{SD})$ of preoperative calcium level was $2.2 \pm 0.2 \mathrm{mmol} / \mathrm{l}$ with range from 2.0 to $2.6 \mathrm{mmol} / \mathrm{L}$ in study subjects (Table I). The mean $( \pm$ SD) of intraoperative, after 24 hours and after 48 hours calcium levels were $1.9 \pm 0.2 \mathrm{mmol} / 1,1.8 \pm 0.2 \mathrm{mmol} / 1$, $1.8 \pm 0.1 \mathrm{mmol} / 1$ respectively in patients with hypocalcaemia. In patient with normocalcaemia, the mean $( \pm \mathrm{SD})$ of intraoperative, after 24 hours and after 48 hours calcium levels were $2.1 \pm 0.1 \mathrm{mmol} / 1, \quad 2.2 \pm 0.2 \mathrm{mmol} / 1, \quad 2.1 \pm 0.1 \mathrm{mmol} / 1$ respectively. The mean difference of intraoperative, after 24 hours and after 48 hours calcium levels were statistically significant $(p<0.05)$ between patient with hypocalcaemia and patient with normocalcaemia in unpaired t-test (Table II ).

The mean $( \pm \mathrm{SD})$ of preoperative PTH was found $36.4 \pm 12.6 \mathrm{pg} / \mathrm{ml}$ in patients with hypocalcemia and $45.3 \pm 23.3 \mathrm{pg} / \mathrm{ml}$ in patients with normocalcemia. The mean $( \pm \mathrm{SD})$ of intraoperative PTH was found $15.5 \pm 8.2 \mathrm{pg} / \mathrm{ml}$ in patients with hypocalcemia and $24.5 \pm 11.8 \mathrm{pg} / \mathrm{ml}$ in patients with normocalcemia. The mean PTH level was significantly declined intraoperatively from preoperative PTH in both hypocalcaemic and normocalcaemic patients. On the other hand intraoperative PTH was statistically significant $(\mathrm{P}<0.05)$ between two groups in Student t-test but preoperative PTH was not statistically significant $(\mathrm{P}>0.05)$ between two groups in Student t-test (Table III).

Intraoperative PTH levels were lower than preoperative PTH levels from $33.9 \%$ to $90.0 \%$ $(\mathrm{p}=.001)$ which is significant in paired t-test (Table IV). 
By Pearson's correlation test we observed a weak correlation between intraoperative PTH and intraoperative calcium $(\mathrm{r}=0.148, \quad \mathrm{p}>0.05)$. Significant correlation between intraoperative PTH $\& 24$ hour's calcium level $(\mathrm{r}=0.240, \mathrm{p}<0.05)$ and intraoperative PTH \& 48 hour's calcium level (r= $0.344, \mathrm{p}<0.05$ ) (Figure 1, 2 and 3).

Intraoperative PTH was $<15 \mathrm{pg} / \mathrm{ml}$ in 27 cases and $\geq 15 \mathrm{pg} / \mathrm{ml}$ in 38 cases. Among hypocalcaemic patients, intraoperative PTH was $<15 \mathrm{pg} / \mathrm{ml}$ in 21 cases and $\geq 15 \mathrm{pg} / \mathrm{ml}$ in 4 cases. Among normocalcaemic patients intraoperative PTH was $<15 \mathrm{pg} / \mathrm{ml}$ in 6 cases and $\geq 15 \mathrm{pg} / \mathrm{ml}$ in 34 cases (Table V).

Sensitivity, specificity, accuracy, positive and negative predictive values were $84.0 \%, 85.0 \%$, $84.6 \%, 77.8 \%$, and $89.5 \%$ respectively. The validity test of the intraoperative PTH level for detection of hypocalcaemia was confirmed by calculating sensitivity, specificity, accuracy, positive and negative predictive values by using the standard formula (Table VI).

Table I: Pre and postoperative serum calcium level of the study subjects at different time interval $(\mathrm{n}=65)$

\begin{tabular}{lcc}
\hline Serum calcium level (mmol/l) & \multicolumn{2}{c}{ All patients (n=65) } \\
\cline { 2 - 3 } & Mean \pm SD & Min-Max \\
\hline Preoperative calcium & $2.2 \pm 0.2$ & $(2.0-2.6)$ \\
Intraoperative (20 minutes after & $2.0 \pm 0.2$ & $(1.6-2.5)$ \\
total thyroidectomy) calcium & $2.0 \pm 0.3$ & $(1.5-2.5)$ \\
After 24 hours (of total & & \\
thyroidectomy) Calcium & & \\
$\begin{array}{l}\text { After 48 hours (of total } \\
\text { thyroidectomy) Calcium }\end{array}$ & $2.0 \pm 0.2$ & $(1.5-2.6)$ \\
\hline
\end{tabular}

Table II: Comparison of intraoperative, after 24 hours and after 48 hours calcium level between patient with hypocalcaemia and patient with normocalcaemia $(\mathrm{n}=65)$

\begin{tabular}{lccc}
\hline \multirow{2}{*}{$\begin{array}{l}\text { Serum calcium level } \\
\text { mmol/l) }\end{array}$} & $\begin{array}{c}\text { Patient with } \\
\text { hypocalcaemia } \\
(\mathrm{n}=25)\end{array}$ & $\begin{array}{c}\text { Patient with } \\
\text { normocalcaemia } \\
(\mathrm{n}=40)\end{array}$ & P value \\
\cline { 2 - 3 } & Mean \pm SD & Mean \pm SD & \\
\hline Intraoperative calcium & $1.9 \pm 0.2$ & $2.1 \pm 0.1$ & $0.001^{\mathrm{s}}$ \\
Range (min-max) & $(1.6-2.5)$ & $(2.0-2.5)$ & \\
After 24 hours calcium & $1.8 \pm 0.2$ & $2.2 \pm 0.2$ & $0.001^{\mathrm{s}}$ \\
Range (min-max) & $(1.5-2.3)$ & $(2.0-2.5)$ & \\
After 48 hours calcium & $1.8 \pm 0.1$ & $2.1 \pm 0.1$ & $0.001^{\mathrm{s}}$ \\
Range (min-max) & $(1.5-1.9)$ & $(2.0-2.6)$ & \\
\hline
\end{tabular}

Hypocalcaemia- If serum calcium level is less than $2.0 \mathrm{mmol} / 1$

Table III: Comparison of preoperative and intraoperative PTH level between patient with hypocalcaemia $(n=25)$ and patient with normocalcaemia $(\mathrm{n}=40)$

\begin{tabular}{lccc}
\hline PTH level $(\mathrm{pg} / \mathrm{ml})$ & $\begin{array}{c}\text { Hypocalcemic } \\
(\mathrm{n}=25)\end{array}$ & $\begin{array}{c}\text { Normocalcemic } \\
(\mathrm{n}=40)\end{array}$ & P value \\
\cline { 2 - 5 } & Mean \pm SD & Mean \pm SD & \\
\hline Intraoperative PTH & $15.5 \pm 8.2$ & $24.5 \pm 11.8$ & ${ }^{\mathrm{a}} 0.001^{\mathrm{s}}$ \\
Range (min-max) & $(3.0-30.4)$ & $(7.6-62.6)$ & \\
Pre operative PTH & $36.4 \pm 12.6$ & $45.3 \pm 23.3$ & ${ }^{\mathrm{a}} 0.084^{\mathrm{ns}}$ \\
Range (min-max) & $(15.5-78.6)$ & $(18.2-145)$ & \\
\hline P value & ${ }^{\mathrm{b}} 0.001^{\mathrm{s}}$ & ${ }^{\mathrm{b}} 0.001^{\mathrm{s}}$ & \\
\hline
\end{tabular}

Table IV: Mean distribution of preoperative and intraoperative serum PTH level of the patients with hypocalcaemia $(\mathrm{n}=25)$

\begin{tabular}{lcc}
\hline Serum PTH level $(\mathrm{pg} / \mathrm{ml})$ & \multicolumn{2}{c}{ Patients with hypocalcaemia $(\mathrm{n}=25)$} \\
\cline { 2 - 3 } & Mean \pm SD & Min - Max \\
\hline Preoperative PTH & $36.4 \pm 12.6$ & $(15.5-78.6)$ \\
Intraoperative PTH & $15.5 \pm 8.2$ & $(3.0-30.4)$ \\
Decreases in percentage & $65.3 \pm 16.7$ & $(33.9-90.0)$ \\
\hline
\end{tabular}

Table V: Number of normocalcaemic and hypocalcaemic patients correlation with intraoperative normal and hypoparathyroid hormone level $(\mathrm{n}=65)$

\begin{tabular}{|c|c|c|c|}
\hline $\begin{array}{l}\text { Intraoperative } \\
\text { parathyroid hormone } \\
\text { (PTH) } \mathrm{pg} / \mathrm{ml}\end{array}$ & $\begin{array}{c}\text { Calcium }<2.0 \\
\text { mmol/l } \\
\text { (Hypocalcaemic } \\
(\mathrm{n}=25)\end{array}$ & $\begin{array}{c}\text { Calcium } \geq 2.0 \\
\mathrm{mmol} / \mathrm{l} \\
(\text { Normocalca } \\
\text { emic) }(\mathrm{n}=40)\end{array}$ & Total \\
\hline $\begin{array}{l}<15 \text { (PTH } 20 \text { minutes } \\
\text { after total } \\
\text { thyroidectomy) }\end{array}$ & 21 & 6 & $27(41.5 \%)$ \\
\hline $\begin{array}{l}\geq 15 \text { (PTH } 20 \text { minutes } \\
\text { after total } \\
\text { thyroidectomy) }\end{array}$ & 4 & 34 & $38(58.5 \%)$ \\
\hline Total & 25 & 40 & 65 \\
\hline
\end{tabular}

Table VI: Sensitivity, specificity, accuracy, positive and negative predictive values of the intraoperative PTH level in diagnosis of hypocalcaemia $(\mathrm{n}=65)$

\begin{tabular}{lc}
\hline Test of validity & Percentage \\
\hline Sensitivity & 84.0 \\
Specificity & 85.0 \\
Accuracy & 84.6 \\
Positive predictive value & 77.8 \\
Negative predictive value & 89.5 \\
\hline
\end{tabular}

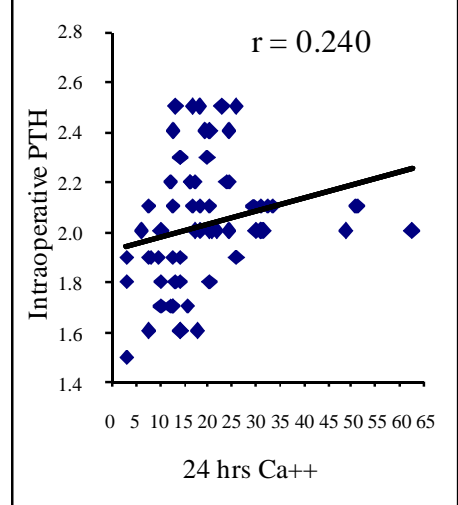

Fig. 2

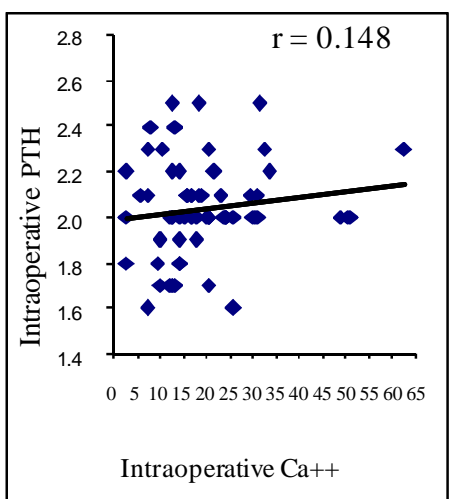

Fig. 1

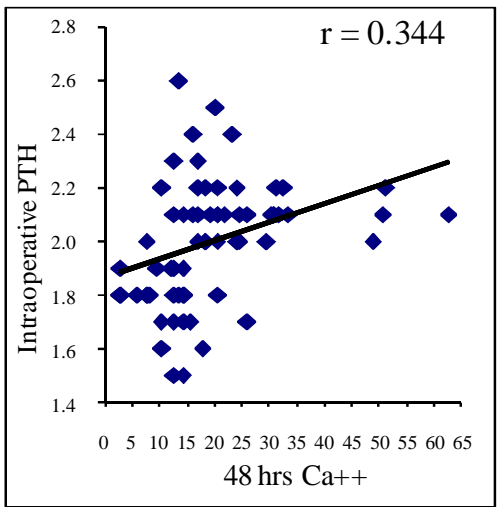

Fig. 3

Correlation between intraoperative PTH with intraoperative, after 24 hours and after 48 hours calcium ( $\mathrm{n}=65)$. 


\section{Discussion}

Postoperative hypocalcaemia is a common problem following thyroid surgery $\mathrm{y}^{\mathbf{3 , 1 4}}$. To focus our study on hypocalcaemia, we considered as hypocalcaemic patients only with a serum calcium level $<2.0$ $\mathrm{mmol} / \mathrm{l}^{16}$. Postoperative hypocalcaemia after total thyroidectomy has been reported to range from $1.3 \%$ to $50 \%{ }^{17}$.

Parathyroid gland insufficiency is the main contributing factor for hypocalcaemia after thyroid surgery. Half life of serum PTH is only 5 minutes that means hypoparathyroidism can take place only few minutes after surgery ${ }^{11}$. Because of the short half-life of $\mathrm{PTH}^{\mathbf{1 8}}$, intraoperative PTH monitoring emerges as an early marker of hypocalcaemia ${ }^{12}$. Now, it has been suggested that PTH assay plays a role in establishing the diagnosis of hypocalcaemia after total thyroidectomy ${ }^{19}$. The purpose of this study is to evaluate intraoperative PTH measurements to predict hypocalcaemia after total thyroidectomy.

In this study, a total 65 cases were evaluated. The mean age of the patients was $39.15 \mathrm{SD} \pm 13.18$ years ranging from 15 to 75 years. Male was $22.5 \%$ and female was $77.5 \%$. Qari $\mathrm{FA}^{\mathbf{2 0}}$ reported that mean age $($ mean \pm SD) was $39.35 \pm 13.97$ which is consistent with this study.

Patients were stratified into the "hypocalcaemic" and "normocalcaemic" groups depending on whether they had postoperative calcium level is less than $2.00 \mathrm{mmol} / \mathrm{l}^{\mathbf{1 6}}$. The mean $( \pm \mathrm{SD})$ of intraoperative, after 24 hours and after 48 hours calcium levels were $1.9 \pm 0.2 \mathrm{mmol} / 1$, $1.8 \pm 0.2 \mathrm{mmol} / 1, \quad 1.8 \pm 0.1 \mathrm{mmol} / \mathrm{l}$ respectively in patients with hypocalcaemia and in patient with normocalcaemia, the mean $( \pm \mathrm{SD})$ of intraoperative, after 24 hours and after 48 hours calcium levels were $2.1 \pm 0.1 \mathrm{mmol} / \mathrm{l}, \quad 2.2 \pm 0.2 \mathrm{mmol} / \mathrm{l}, \quad 2.1 \pm 0.1$ $\mathrm{mmol} / \mathrm{l}$ respectively.

In this study, the incidence of hypocalcaemia was $38.5 \%$ after total thyroidectomy. Post operative hypocalcemia after total thyroidectomy has been reported to range from $1.3 \%$ to $50 \%{ }^{17}$. Incidence of hypocalcaemia was within the international norms.

In this study, asymptomatic hypocalcaemia was found in 22 patients and symptomatic hypocalcaemia was found in 3 patients that is $12 \%$. In a study of 100 study populations, the percentage of symptomatic hypocalcaemia was $9 \%$ and in a study with 448 study populations, the symptomatic hypocalcaemia was $15 \%$. So, the result of this study is within the international norms.
Postoperative hypocalcaemia may have a delayed onset. The lowest calcium levels are typically recognized 24 to 48 hours after thyroidectomy ${ }^{10}$. In this study, total hypocalcaemic patients were 25 . These hypocalcaemic patients were different individuals. Hypocalcaemia was developed in 15 cases during intraoperatively. In another 7 cases hypocalcaemia developed after 24 hours and another 3 hypocalcaemia developed after 48 hours of total thyroidectomy. The mean difference of intraoperative calcium, after 24 hours calcium and after 48 hours calcium were statistically significant $(p<0.05)$ between patient with hypocalcaemia and patient with normocalcaemia in Student t-test. So, the hypocalcaemia developing time is consistent with the others.

Initially intraoperative measurement of parathyroid hormone level was used in parathyroidectomy due to hyperparathyroidism. Afterwards, there are many reports demonstrating that the intraoperative PTH assay could predict hypocalcaemia after thyroid surgery. Richards ML et al ${ }^{\mathbf{8}}$ evaluated the role of intraoperative PTH levels as a predictor of hypocalcaemia in patients undergoing total thyroidectomy and reported that the most predictive value of PTH was at 20 minutes after removing the thyroid gland. In the present study, blood was drawn preoperatively, 20 minutes after excision of both lobes of thyroid gland (Intraoperatively), after 24 hours and after 48 hours of total thyroidectomy which is consistent with the other studies.

Patients who became hypocalcaemic were more likely to have a PTH level below $15 \mathrm{pg} / \mathrm{ml}^{\mathbf{1 3 , 2 2}}$. In this study, level of serum PTH was $15 \mathrm{pg} / \mathrm{ml}$ as a predictor of hypocalcaemia after total thyroidectomy, which is consistent with the others.

Markuszewska MP et $\mathrm{al}^{\mathbf{1 0}}$ found correlation between intraoperative PTH level after thyroid surgery and the development of hypocalcaemia. In the present study, statistical analysis by Student ttest revealed that the mean PTH was significantly declined intraoperatively from preoperative PTH in both hypocalcaemic and normocalcaemic groups. On the other hand intraoperative PTH was statistically significant $\quad(\mathrm{P}<0.05) \quad$ between hypocalcaemic and normocalcaemic groups but pre operative PTH was not statistically significant $(\mathrm{P}>0.05)$ between two groups.

In relation to base PTH values, PTH levels were lower at the end of operation from $22.5 \%$ to $84.7 \%$ after total thyroidectomy ${ }^{23}$. In this study, in hypocalcaemic patients, intraoperative PTH levels were lower than preoperative PTH from $33.9 \%$ to $90.0 \%,(p=.001)$. This observation is significant and consistent with the other. 
Intraoperative PTH was assessed, weak correlation was found between intraoperative PTH and intraoperative calcium level. Significant correlation was found between intraoperative PTH level and development of hypocalcaemia after 24 hours of total thyroidectomy (Pearson coefficient $r=0.240$; $\mathrm{p}<0.05)$ and significant correlation was also found between intraoperative PTH level and development of hypocalcaemia after 48 hours of total thyroidectomy (Pearson coefficient $r=0.344$; $\mathrm{p}<0.05)$. Among hypocalcaemic patients, intraoperative PTH was $<15 \mathrm{pg} / \mathrm{ml}$ in 21 cases and $\geq 15 \mathrm{pg} / \mathrm{ml}$ in 4 cases. Among normocalcaemic patients intraoperative PTH was $<15 \mathrm{pg} / \mathrm{ml}$ in 6 cases and $\geq 15 \mathrm{pg} / \mathrm{ml}$ in 34 cases. Our results indicate that the intraoperative PTH assay can predict the group at risk for hypocalcaemia. In addition, an intraoperative decrease in PTH correlated with the postoperative calcium level.

Chindavijak $\mathrm{S}^{\mathbf{2 2}}$ analyzed the PTH level at 20 minutes after total thyroidectomy for prediction of post thyroidectomy hypocalcaemia. The sensitivity, specificity, and accuracy for prediction of post total thyroidectomy hypocalcaemia of his study were $85 \%, 80 \%$, and $83.3 \%$ respectively. In the present study, the PTH level at 20 minutes after total thyroidectomy was studied and evaluated. Sensitivity was $84.0 \%$, specificity was $85.0 \%$, accuracy was $84.6 \%$, positive predictive value $77.8 \%$, and negative predictive value was $89.5 \%$ in this study. So, sensitivity, specificity, accuracy, positive and negative predictive value of our study is consistent with the other. With compare to other study, single assay of intraoperative PTH at 20 minutes of total thyroidectomy can be demonstrated as a predictor of hypocalcaemia. The symptoms of hypocalcaemia make patients have to stay in hospital for observation of calcium level after the symptoms occur. However, only 3 hypocalcaemic patients developed symptoms and all patients with a PTH level at 20 minutes more than $15 \mathrm{pg} / \mathrm{ml}$ did not develop symptoms of hypocalcaemia.

Conclusion: The early prediction of hypocalcaemia could be made by single assay of intraoperative serum PTH level at 20 minutes after total thyroidectomy. Because of high sensitivity, specificity, accuracy and negative predictive value, intraoperative serum PTH can be used in prediction of hypocalcaemia in total thyroidectomy patients.

\section{Acknowledgement}

I would like to deep gratitude and thanks towards the all patients on whom this study was done, without whom this study would be impossible. Wish them all happy and healthy life.

\section{References}

1. Bhattacharyya N, Fried MP. Assessment of the morbidity and complications of total thyroidectomy. Arch Otolaryngol Head Neck Surg. 2002;128:389-392.

2. Husein M, Hier MP, Hadi KAA, Black M. Predicting calcium status post thyroidectomy with early calcium levels. Otolaryngol Head Neck Surg. 2002; 127: 289293.

3. Quiros RM, Pesce CE, Wilhelm SM, Djuricin G, Prinz RA. Intraoperative parathyroid hormone levels in thyroid surgery are predictive of postoperative hypoparathyroidism and need for vitamin D supplementation. The American Journal of Surgery. 2005; 189: 306-309.

4. McLeod IK, Arciero C, Noordzij JP, Stojadinovic A, Peoples G, Melder PC, Langley R, Bernet V, Shriver $\mathrm{CD}$ et al. The use of rapid parathyroid hormone assay in predicting postoperative hypocalcemia after total or completion thyroidectomy. THYROID. 2006; 16(3): 259-265.

5. Abboud B, Sargi Z, Akkam M, Sleilaty F. Risk factors for postthyroidectomy hypocalcemia. J Am Coll Surg. 2002; 4(195): 456-461.

6. Fahmy FF, Gillett D, Lolen Y, Shotton JC. Management of serum calcium levels in post thyroidectomy patients. Clin. Otolaryngol. 2004; 29: 735-739.

7. Harris VW, Jan DBS. Postoperative hypoparathyroidism: Medical and surgical therapeutic options. THYROID. 2009; 19(9): 967-973.

8. Richards ML, Casey JB, Pierce D, Strinck WE. Intraoperative parathyroid hormone assay: An accurate predictor of symptomatic hypocalcaemia following thyroidectomy. Arch Surg. 2003; 138: 632-636.

9. Nahas ZS, Farrag TY, Lin FR, Belin RM, Tufano RP. A safe and cost effective short hospital stays protocol to identify patients at low risk for the development of significant hypocalcaemia after total thyroidectomy. Laryngoscope. 2006; 116: 906-910.

10. Markuszewska MP, Kobiela J, Stefaniak T, Andrzej J. Lachinski AJ, Sledzinski Z. Postoperative PTH measurement as a predictor of hypocalcaemia after thyroidectomy. Polski, Przeglad Chirurgiczny. 2010; 82(1): 24-28.

11. Lindblom P, Westerdahl J, Bergenfelz A. Low parathyroid hormone levels after thyroid surgery: A feasible predictor of hypocalcaemia. Surgery. 2002; 131: 515-520.

12. Lam A, Kerr PD. Parathyroid hormone: An early predictor of post thyroidectomy hypocalcaemia. Laryngoscope. 2003; 113: 2196-2200.

13. Asari R, Passler C, Kaczirek K, Scheuba C, Niederle B. Hypoparathyroidism after total thyroidectomy. Arch Surg 2008; 143(2): 132-137.

14. Khafif A, Pivoarov A, Medina JE, Avergel A, Gil Z, Fliss DM. Parathyroid hormone: A sensitive predictor of hypocalcemia following total thyroidectomy. Otolaryngology-Head and Neck Surgery. 2006; 134: 907-910. 
15. Vescan A, Witterick I, Freeman J. Parathyroid hormone as a predictor of hypocalcaemia after thyroidectomy. The Laryngoscope. 2005; 115(12): 2105-2108.

16. Toniato A, Boschin IM, Piotto A, Pelizzo MR, Sartori P. Thyroidectomy and parathyroid hormone: Tracing hypocalcemia-prone patients. The American Journal of Surgery. 2008; 196: 285-288.

17. Rajinikanth J, Paul MJ, Abraham DT, Selvan B, Nair A. Surgical audit of inadvertent parathyroidectomy during total thyroidectomy: Incidence, risk factors, and outcome. Medscape J Med. 2009; 11(1): 29-36.

18. Sokoll LJ, Drew H, Udelsman R. Intraoperative parathyroid hormone analysis: A study of 200 consecutive cases. Clinical Chemistry. 2000; 46(10): $1662-1668$.

19. Fabio FD, Casella C, Bugari G, Lacobello C, Salerni B. Identification of patients at low risk for thyroidectomy- related hypocalcemia by intraoperative quick PTH. World J Surg. 2006; 30: 1428-1433.

20. Qari FA. Estimation of ionized calcium levels after thyroidectomy at King Abdul Aziz university hospital (Jeddah). Pak J Med Sci. 2004; 20(4): 325-330.

21. Gac EP, Cabané TP, Amat VJ, Huidobro GF, Rossi FR, Rodríguez FF, Ferrada VC, Cardemil RF. Incidence of hypocalcemia after total thyroidectomy. Rev Med Chil. 2007; 135(1): 26-30.

22. Chindavijak S. Prediction of hypocalcaemia in postoperative total thyroidectomy using single measurement of intraoperative parathyroid hormone level. J Med Assoc Thai. 2007; 90(6): 1167-1171.

23. Lewandowicz M, Kuzdak K, Zbigniew Pasieka Z. Intraoperative parathyroid hormone level as a predictor of post thyroidectomy hypoparathyroidism. Polski Przeglad Chirurgiczny. 2009; 81(8): 340-347. 